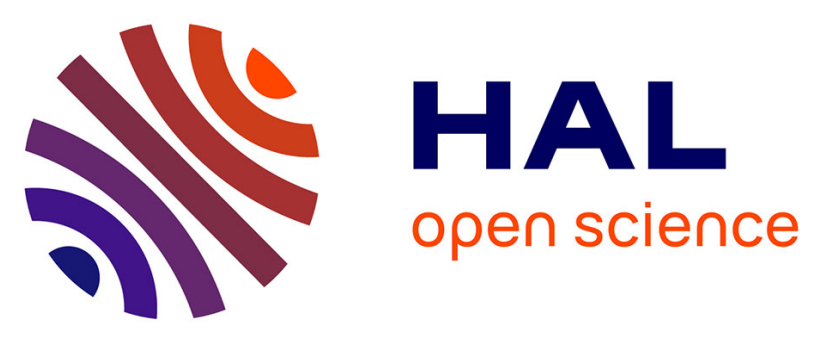

\title{
Development of Web-Based Learning Scenarios in the Semantic Web - A Connection of Didactical Aspects and Ontological Structures
}

Sven Hofmann

\section{- To cite this version:}

Sven Hofmann. Development of Web-Based Learning Scenarios in the Semantic Web - A Connection of Didactical Aspects and Ontological Structures. 11th IFIP World Conference on Computers in Education (WCCE), Jul 2017, Dublin, Ireland. pp.161-168, 10.1007/978-3-319-74310-3_18 . hal01762904

\author{
HAL Id: hal-01762904 \\ https://hal.inria.fr/hal-01762904
}

Submitted on 10 Apr 2018

HAL is a multi-disciplinary open access archive for the deposit and dissemination of scientific research documents, whether they are published or not. The documents may come from teaching and research institutions in France or abroad, or from public or private research centers.
L'archive ouverte pluridisciplinaire HAL, est destinée au dépôt et à la diffusion de documents scientifiques de niveau recherche, publiés ou non, émanant des établissements d'enseignement et de recherche français ou étrangers, des laboratoires publics ou privés. 


\title{
Development of Web-Based Learning Scenarios in the Semantic Web - a Connection of Didactical Aspects and Ontological Structures
}

\author{
Sven Hofmann \\ Chair of didactic of computer science, Technical University Dresden, Germany \\ sven.hofmann@tu-dresden.de
}

\begin{abstract}
This paper investigates how teachers can be supported and guided in the planning of web-based learning scenarios. Using a graphical user-interface (GUI) the teachers should be able to choose existing learning-concepts and to realize them by web-based learning. Based on classical models of didactics a class-hierarchy of identifiers for learning-phases, learning-methods and learning-tools was developed, which is already in use by teachers in their practical work. After empirical studies this term set was transferred to scenarios of web-based learning. Didactical templates and patterns are derived. The developed term set and a competency model lead to a class-hierarchy, which is represented by an ontology for the semantic web. This ontological structure in combination with the GUI has to enable the saving, loading and sharing of learning scenarios based on web-standards. Using editors for creating the sets of meta-data and the ontology, this work offers first prototypical solutions. As part of an outlook on further research options for the mapping of the ontological structure into a learning platform are discussed. The aims of this investigation are first solutions to the largely automatic transfer of a planned learning scenario into a course structure of the chosen learning platform.
\end{abstract}

Keywords. Web-based learning; didactical models; ontology; learning platform; competency

\section{Introduction}

During their studies the students in teacher training learn much about didactical models, concepts and principals, which have evolved historically and which are used in Germany's schools. There are two separate parts of the didactics training - the general didactics and the specialist didactics in the two subjects of school having chosen by the students. Often they learn three different definitions of didactical terms for the same issue. These term settings are very different not only between the separate faculties of a particular university but rather between the universities of Germany. In addition the use of web-based learning scenarios required other notions and every content management system as part of a learning platform includes their own objects and structures.

A guideline for teachers would be able to support the planning and realizations of web-based learning scenarios based on the didactical terms and transfer them into learning management systems. The frontend is a graphical user interface (GUI) which 
allows setting a sequence of learning-phases into a timeline in combination with learning methods and learning tools. The question was - how to represent the triples of phases, methods and tools for saving, reusing, editing and sharing on the web? The solution is an ontology, developed in the context of this work. Later it should be possible to export this ontological structure to different learning-platforms for creating a new e-learning scenario. So the teacher has the chance to plan and realize web-based learning scenarios using his own term setting without a deeper knowledge of the special object structure in the knowledge management system.

\section{Didactical models and concepts}

\subsection{Classical didactical models}

During their teacher training program the students get comprehensive knowledge about didactical models. They use them in the practical exercises and in their future professional work. Especially the model of educational-theoretical didactics by Klafki [1], the model of teaching-theoretical didactics by Heimann and Schulz [2] and also the model of curricular didactics by Mager, Möller and Meyer [3][4] stand on the agenda of the didactical education. These classical models are based on a learning goal oriented approach and focus on input oriented teaching-learning scenarios.

Studies such as PISA [5] and PISA-E [6] showed among other findings the need for a standardization of education systems in the German states. They made clear, the educational process with rigid curriculum requirements is no longer appropriate in the international and federal-state context.

As a result a transition from input oriented teaching towards output orientation takes place. Educational standards for the control of the educational process got more into focus. The aim of these regulating standards is to make the different qualifications in the 16 German federal states comparable and replace the rigid curriculum guidelines by defined core competencies.

Learning scenarios based on an action theoretical principle with their phases start, work and transfer of the learning results become more important. [7] The teaching at German schools is increasingly determined by competency orientation and uses didactical scenarios which are focused on the development of self-organized thinking and acting based on different learning content. [8] The transformation from input oriented to output oriented teaching leads to a greater variety of methods. Didactic principles like problem orientation, redundancy and holism flow stronger into the planning and implementation of learning scenarios. [9] Teaching concepts like "webbased learning", "flipped classroom" bring more intensive use of digital media and support the communication between teachers and learners. This opens a new freedom of action in which the didactic aspects and the enrichment of the method repertoire are of primary importance.

\subsection{Set of didactical terms}

The realization of new learning concepts and the use of digital media caused the enlargement of the didactical term sets but also the magnification of their inconsistency. For the same issues different identifiers are in use. As an example of an 
identifier of the individual time sections in a learning scenario there are terms like "lesson phase", "learning section" and others in use. Here serious differences are to be seen not only between the universities but also between the individual faculties of the same university.

For the planning and realization of web-based learning scenarios platforms like Moodle or OPAL are available. These learning platforms contain a predefined quantity of course objects (e.g. internal pages, tests, tasks) being not conform to the didactical term set. This implies the necessity of unification of the term set in didactical context for their subsequent mapping in the object quantity of the learning platform.

In the first step a term set has been derived from classic didactical models and established teaching concepts. This set was evaluated with teachers of German schools in 2 stages. The first survey was carried out using a guide controlled interview. In this case a semi open card sorting gave as a result a first categorization of the didactical terms.

After completion of the cluster analysis and adaption of the term set a second survey by questionnaire took place with the same sample. This result was an increase of the scatter goodness from $48,1 \%$ after the first survey to $78,1 \%$ after the second.

Thus a largely standardized term set originated, which classifies the didactical terms for planning and realizing of web-based learning scenarios in a hierarchy of three classes learning phase $(p)$, learning method $(m)$ and learning tool $(t)$. [11]

\subsection{Templates and patterns}

The contemplation of possible combinations of learning methods (m) and learning tools (t) emerges frequently used $(\mathrm{m}, \mathrm{t})$-pairs which represent typical teaching situations as a template and can be mapped in special course objects of the learning platforms.

The combination of each learning phase $(p)$ with a $(m, t)$-template effects a $(p, m, t)$ triple describing a concrete teaching scenario. The sequencing of several $(\mathrm{p}, \mathrm{m}, \mathrm{t})$ Triples gives a complete learning scenario. [11]

In practice proven learning-scenarios also consider didactical principles and institutional conditions. [12] Therefrom teaching concepts can be derived which are to be realized by web-based learning in learning platforms.

In view of the subsequent mapping of a scenario in the course structure on learning platforms the use of a standardized description language for the patterns makes sense. Solutions for the representation of standardized teaching scenarios by patterns using a special pattern language already exist. For example in context of the Pedagogical Patterns Project special patterns for the planning and execution of seminars [13] or of running a course [14] were developed. Fourteen didactical patterns to typical education scenarios in high schools were collected by Bergin supporting professors in their work. [15] All of these examples use their own special sets of didactical terms.

The special pattern language is largely unified. In these patterns language statements about problem, requirements, context, solution and crosslinking are included. [16] This pattern language should be transferred in the context of school education. Goodyear (2005) follows the idea to provide teachers with set of educational design ideas represented by design patterns. Examples for tasks like 
discuss, debate, summarize with different organizational forms and learning tools are released.

Using structured descriptions in pattern language these web-based learning scenarios based on an own term set which seems not completely compatible with the terms in didactics for German schools.

The developed graphical planning tool based on the evaluated set of didactical terms. For the following proven teaching concepts descriptions in pattern language are already prepared: [11]

- Concept of project work

- Concept of open learning

- Concept of problem-solving learning

- Concept of science oriented learning

- Concept of programmed instruction

The classification of the didactical term set in a formalized class hierarchy and the deriving of didactical templates and patterns form the base for a development environment, which supports the planning and realization of web-based learning scenarios and can be stored as an ontological structure in the net.

In the actual status a combination of all phases, methods and tools is possible. A compilation of suitable $(\mathrm{p}, \mathrm{m}, \mathrm{t})$-triples to prefabricated design patterns has to be implemented after a test phase with teachers.

\subsection{Integration of a competency model}

The research also focused on the inclusion of a competency model. Here a class hierarchy was derived, which contains in the first level the main classes of competencies - learning-competence, media-competence, social-competence and selfcompetence. These classes resulted from analyses of established competence models e.g. GERS [17] and selected curricula from Germany and Austria. [18], [19], [20].

The competency model will be integrated in a further stage of the development environment. Here the user will be able to set a prescription for the degrees of competencies and their current degrees of the learners too.

A later version will provide a consulting function for teachers by accessing of this competence model. Depending on the differences between the prescriptive competence and the current degree - the learning needs - notes on particularly suitable templates will be given to the users. This consulting function has to be an adaptive system. So the teacher has the opportunity to bring his own experience into the system after the use of $(\mathrm{p}, \mathrm{m}, \mathrm{t})$-triples for the competence development in webbased learning scenarios. [11]

\section{Ontology}

\subsection{Representation of didactical term sets}

The available, largely formalized term set allows a structured development of webbased learning scenarios. The teachers will be guided by an environment which supports the data managing (saving, editing and sharing) of the scenario. 
The developed planning tool should meet the following requirements:

- The learning scenario has to be planned and realized using the existing didactical term set.

- The result of the planning process is filed on the web and provides opportunities for reusing, editing, sharing, publishing and so on.

- The filing of the scenario complies with the standards for the web-based representation of learning processes (e.g. IMS-Learning Design, LOM - Learning Object Metadata). [11]

It became evident that an ontology meets these requirements for representation of learning scenarios. The exploration of existing ontologies, especially of their conceptual structure, shows particularly application areas in information retrieval, eCommerce and knowledge management. [21] By mapping of web-based learning processes in an ontology a new area of use is opened.

Ontologies can be categorized by the level of generalization in top-level-ontology; domain-level-ontology and application-level-ontology ordered descending. The didactical term set is first placed in a context-independent top-level-ontology. This is to be considered as prototype and will change to a domain-level-ontology by developing a concrete learning scenario in the context of a specific teaching subject.

For mapping the didactical term set in an ontological structure the Web Ontology Language (OWL) is in use. This semantic markup language allows the implementation of the terms in a class hierarchy, the allocation of special attributes and the definition of relations between the classes. Ontologies formulated in OWL meet the following requirements on a technological level:

- The representation of ontologies on the web is possible.

- Interactions to other ontologies are supported.

- Special classes, relations and attributes are defined.

- The syntax is based on XML and confirms to W3C.

- The semantic representation of content corresponds to the standard. [11]

Regarding the standardized representation of learning content ontologies, OWL also meets special requirements on the didactical level:

- The learning objects and their relations are described based on formalized languages.

- The semantic and elementary dependencies of the objects are formulated by ontology vocabulary.

- Logical compositions are defined by regulations.

In the present ontology for example it is possible to declare a phase in the class LearningPhase as successor of another. Thus a sequencing of the phases is possible and so a learning scenario is created. An object of the class LearningMethod is related to an object of the class LearningTool by the relation has_to_use.

The creation of ontology is supported by an editor. In this case the editor Protègè2000 is in use. This is a frame based tool which is available as Open Source 
application and has a worldwide user-community. The development environment can be extended in the functionality by plugins. [10]

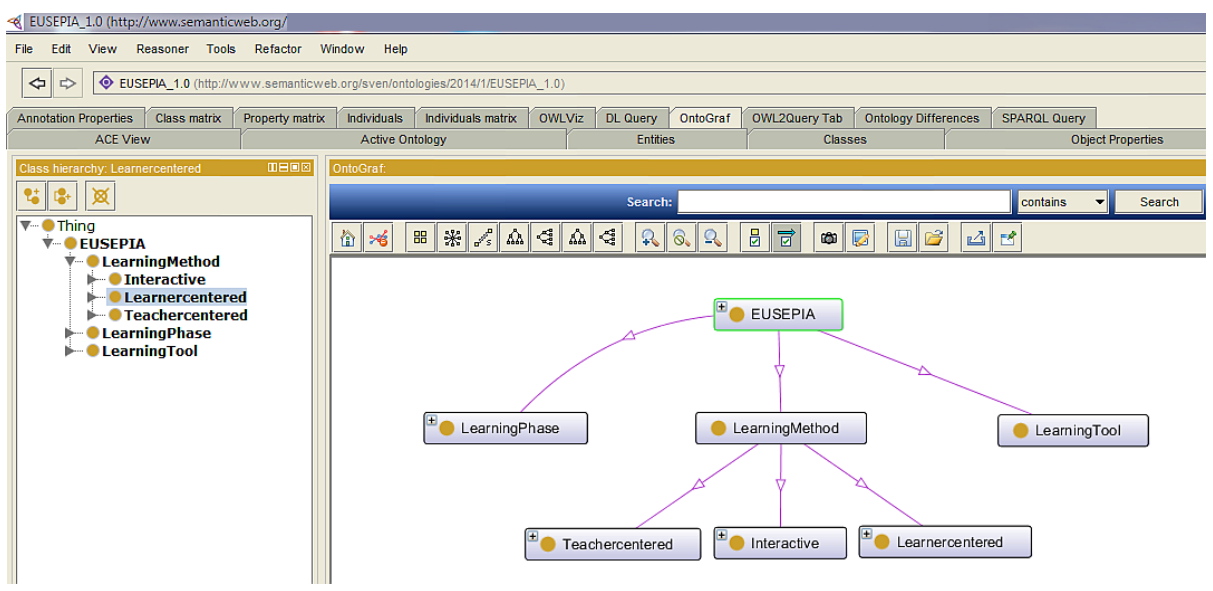

Fig. 1. Representation of ontology EUSEPIA in protègè

The ontology of the evaluated didactical term set forms the base of the surrounding development environment as a graphical user interface. It is set to the educational server of Saxony and can be use not only for the planning of the own learning scenarios but also for their sharing and further developing.

\subsection{Graphical user interface (GUI)}

A graphical user interface (GUI) is placed on the ontology. The construct of GUI and ontology is named EUSEPIA (in German: "Entwicklungsumgebung zur Strukturierung von E-Learning-Prozessen in der Ausbildung", in English: Development Environment for structuring e-learning scenarios in education.) It allows the planning of learning scenarios by setting $(\mathrm{p}, \mathrm{m}, \mathrm{t})$-triples on a timeline. The client-server-structure manages the filing on the server sided ontology.

As part of a complex internship for students of media computer science first software solutions were created. The GUI and also functions for the managing of data exchange with the ontology are capable of work

The client is a web application using different screens and supporting the teachers in their planning of learning scenarios intuitively. An implemented manager administers the scenarios and allows to publish the own scenarios and to make them available to other teachers. So a collaborative work between teachers is possible.

\subsection{Summary, current status}

The creation of EUSEPIA came out of the necessity to bridge the gap between the conceptual world of didactics and the objects in learning platforms. This will enable teachers to plan scenarios for web-based learning with their own didactical term set and to realize them without deeper knowledge about the internal structure of learning platforms. 
A two-staged evaluated term set is the base which is in use in the teacher training of students and in the daily practical work of the teachers. The connecting element is an ontology, where the planned learning scenario is mapped in. This ontology was developed by the use of editors and oriented to the standards of software development. A GUI supports the user in their planning work. Actually this platform and first tools for saving, editing and sharing of scenarios are capable to test.

The client-server-architecture allows a completely web-based planning and the collaborative work with other teachers.

\section{Outlook}

After the further completing of the development environment the tool will be set on the education server in Saxony. The responsive layout has to be further developed.

The Saxon Universities and high schools cooperate on a common Online Platform for Academic Learning (OPAL). Meanwhile this learning platform is available as parallel instance for the schools in Saxony. After the completion of the development work on EUSEPIA the creation of an interface to OPAL-school is planned. This will enable the integration of EUSEPIA as an authoring tool into the learning platform. So the teachers will be able to plan scenarios with the development environment and to generate an e-learning course largely automated.

It becomes clear that a lot of further development work is ready for realization. The project EUSEPIA has high potential for the establishing of web-based learning at schools by supporting teachers in their endeavour to serve a contemporary education by a meaningful use of digital media.

\section{References}

1. Klafki, W.: Die bildungstheoretische Didaktik im Rahmen kritisch-konstruktiver Erziehungswissenschaft. Oder: Zur Neufassung der Didaktischen Analyse. In Gudjons, H., Winkel, R. (eds.) Didaktische Theorien. PB-Bücher Bergmann + Helbig, Hamburg, 13-34 (2011)

2. Schulz, W.: Die lehrtheoretische Didaktik Oder: Didaktisches Handeln im Schulfeld. Modellskizze einer professionellen Tätigkeit. In Gudjons, H., Winkel, R. (eds.) Didaktische Theorien. PB-Bücher Bergmann + Helbig, Hamburg, 35-56 (2011)

3. Mager, R. F.: Lehrgang zur Formulierung von Lernzielen. http://www.phsg.ch/Portaldata/1/Resources/bps_sek_i/zxtranet/ausbildungsunterlagen/Le hrgang_zur_Formulierung_von_Lernzielen.pdf, accessed 3 August 2012 (2010)

4. Möller, C.: Die curriculare Didaktik Oder: Der lernzielorientierte Ansatz. In Gudjons, H., Winkel, R. (eds.) Didaktische Theorien. PB-Bücher Bergmann + Helbig, Hamburg, 7592 (2011)

5. OECD: The PISA 2003 assessment framework. Mathematics, reading, science and problem solving knowledge and skills. OECD, Paris (2003)

6. Baumert, J.: Pisa 2000 - die Länder der Bundesrepublik Deutschland im Vergleich. PISAE. Leske + Budrich, Opladen (2002)

7. Zimmer, G.: Aufgabenorientierte Didaktik des E-Learning. Handbuch E-Learning, 4.Erg.-Lfg. (2003) 
8. Baumgartner, P.: Taxonomie von Unterrichtsmethoden. Ein Plädoyer für didaktische Vielfalt. Waxmann, Münster (2011)

9. Sander, W.: Ein didaktischer Werkzeugkoffer: Tools für die Planung von Lernumgebungen http://studienseminar.rlp.de/fileadmin/user_upload/studienseminar.rlp.de/bbnr/Praktika/Sander_Didaktische_Prinzipien.pdf, accessed 19 Jan 2017 (2009)

10. Gómez-Pérez, A., Fernández-López, M., Corcho, O.: Ontological engineering. With examples from the areas of knowledge management, e-commerce and the semantic Web. Advanced information and knowledge processing. Springer, London, Berlin, Heidelberg (2010)

11. Hofmann, S.: E-Learning und ontologisch strukturierte Planung webbasierter Lehr-LernSzenarien. Entwicklung eines Leitfadens für Lehrende zur didaktisch-methodischen Umsetzung webbasierter Lehr-Lern-Szenarien im Kontext gymnasialen Unterrichts. Logos Berlin, Berlin (2015)

12. Jank, W., Meyer, H.: Didaktische Modelle. Cornelsen Scriptor, Frankfurt am Main (1994)

13. Fricke, A., Völter, M.: SEMINARS. A Pedagogical Pattern Language about teaching seminars effectively. http://www.voelter.de/data/pub/tp/tp.pdf, accessed 5 Jun 2014. (2000)

14. Eckstein, J.: Learning to Teach and Learning to Learn. Running a Course. http://www.pedagogicalpatterns.org/examples/LearningAndTeaching.pdf, accessed 20 Jan 2017 (2000)

15. Bergin, J.: Fourteen Pedagogical Patterns. http://csis.pace.edu/ bergin/PedPat1.3.html. accessed 20 Jan 2017 (2000)

16. Moura Filho, C. O. de, Derycke, A.: Pedagogical Patterns and Learning Design: When Two Worlds Cooperate. http://dspace.ou.nl/bitstream/1820/474/9/09_DBU_review.pdf, accessed 20 Jan 2017 (2005)

17. Council of Europe (2001): Common European framework of reference for languages. Learning, teaching, assessment. Cambridge, U.K: Press Syndicate of the University of Cambridge.

18. Kerres, Michael (2012): Mediendidaktik. Konzeption und Entwicklung medien-gestützter Lernangebote. 3. Aufl. München: Oldenbourg, R.

19. Reisse, Wilfried (2008): Kompetenzorientierte Aufgabenentwicklung. Ein Lehrerhandbuch für die Sekundarstufen. Köln: Aulis-Verl. Deubner.

20. Sächsisches Staatsministerium für Kultus (2013): Lehrplan Gymnasium - Mathematik. Unter Mitarbeit von Sächsischen Bildungsinstitut. Hg. v. Sächsisches Staatsministerium für Kultus. Dresden. Online http://www.schule.sachsen.de/lpdb/web/downloads/1530_lp_gy_mathematik_2013.pdf?v 2, zuletzt aktualisiert am 30.07.2013.

21. Meszaros, G., Doble, J.: A Pattern Language for Pattern Writing. http://hillside.net/index.php/a-pattern-language-for-pattern-writing, accessed 20 Jan 2017 (2013)

22. Kraus, U.: ERP-OnTo-PDM: Konzept und prototypische Realisierung einer ontologiebasierten ERP/PDM Kopplung mittels XML-Technologie. Dissertation. http://dnb.info/969650787/3, accessed 26 April 2013 (2003) 